\title{
Perceptions of Factors Influencing the Career SuCCess of Professional ANd Business WoMen IN SOUTH AFRICA
}

\author{
Marianne Doubell and Miemie Struwig \\ School of Management Sciences, Nelson Mandela Metropolitan University \\ Accepted: April 2014
}

This article reports on an empirical study that investigated factors influencing women's career success. Statistics relating to the field of women in management indicate that, worldwide, women are underrepresented in executive and decision-making positions. Women face unique challenges in their career pursuit that may prevent them from moving up to executive positions. A framework to investigate the factors influencing career success indicates that factors such as demographics, personality, culture, barriers, external and internal support impact on the career success of women. This study surveyed a sample of 301 professional and business women in South Africa. The results of the empirical survey showed that there are statistical significant relationships between groups of women based on their demographics and their perceptions of the factors that influence their career success.

Key words: women management, gender parity, career success

JEL: M19

\section{1}

\section{Introduction}

The South African Employment Equity Act 55 of 1998 (South Africa, 1998) affirms women's right to equal employment opportunities; yet the representation of South African women in top management has declined from 3.9 per cent in 2008 to 3.6 per cent in 2012 (BWA, 2012). Although studies (Eagly \& Carli, 2003; Paton, 2008; Yáñez \& Moreno, 2008) show that women's leadership style ensure their suitability for management positions, women are still under-represented in these positions. Traditionally, the discourse on women's position in society evolved out of feminist rhetoric and can be traced back to the nineteenth century (Murgolo-Poore, 2006). However, it was only during the past two decades that the research focus shifted to women in business and management (Bilimoria \& Piderit, 2007). Research within the domain of women in management attributes the under-representation of women at the executive level to a multitude of barriers inhibiting women's progress beyond the so-called glass ceiling (Simpson \&
Altman, 2000; Bagues \& Estev-Volart, 2010; Daft, 2010). The disproportionate number of males in leadership positions perpetuates socialised patriarchal norms, thereby maintaining this invisible barrier (Falk \& Grizard, 2003).

Census statistics, however, indicate that some women do succeed in progressing to the top (BWA, 2012). Investigating the characteristics and enabling environments associated with women who succeed in their professional careers may be a critical step in understanding why women are under-represented in top management positions worldwide (Duffy et al., 2006). However, the major contributing factors to women's career advancement to leadership positions are not yet clear, nor do we know which of the factors culminating in the glass ceiling constitute the major barriers to their career advancement. In order to contribute to an understanding of the factors influencing women's career success, this article reports on research conducted that investigated the characteristics and the enabling environments associated with women who have succeeded in their professional careers. 
2

\section{Literature review}

In South Africa, substantial progress in women's advancement has been seen over the past decade. The Grant Thornton International Business Owners Survey of 2004 (Grant Thornton, 2005) ranks South Africa third on the list of countries with the highest representation of women in senior positions and eighth globally on the list of women in senior management positions. However, males continue to comprise the largest percentage of incumbents at the senior executive level.

Since 2004, the Business Women's Association of South Africa (BWASA) has been conducting an annual census to analyse, on an ongoing basis, women on boards and in executive management of public companies (BWA, 2012). Table 1 shows the percentage of women in management positions.

Table 1

Year-to-year comparison of women in management positions in South Africa

\begin{tabular}{|l|c|c|c|c|c|}
\hline \multicolumn{1}{|c|}{ Management position } & $\mathbf{2 0 1 2}$ & $\mathbf{2 0 1 1}$ & $\mathbf{2 0 1 0}$ & $\mathbf{2 0 0 9}$ & $\mathbf{2 0 0 8}$ \\
\hline CEOs/MDs & $3.6 \%$ & $4.4 \%$ & $4.5 \%$ & $3.6 \%$ & $3.9 \%$ \\
\hline Chairpersons & $5.5 \%$ & $5.3 \%$ & $6.0 \%$ & $5.8 \%$ & $3.9 \%$ \\
\hline Directors & $17.1 \%$ & $15.8 \%$ & $16.6 \%$ & $14.6 \%$ & $14.3 \%$ \\
\hline Executive Managers & $21.4 \%$ & $21.6 \%$ & $19.3 \%$ & $18.6 \%$ & $25.3 \%$ \\
\hline
\end{tabular}

Source: BWA (2012)

The year-to-year comparison of percentages shown in Table 1 illustrates a positive trend in the representivity of women in management positions up to 2010 , followed by a downward swing in 2011 and 2012.

\subsection{Factors influencing the career success of women}

Career success in this study was the dependent variable. The purpose of the study was, therefore, not to measure success. Although there are many definitions of success, for the purposes of this study, career success is defined as progression to the executive management or leadership level in the course of one's career. The factors commonly reported in existing literature to have an influence on success, are demographics, career barriers, personality traits, cultural factors, external support and internal support.

\subsubsection{Demographics}

The influence of background demographics on professional success is multi-facetted, ranging from birth order to socio-economic status. Literature (Eckstein, 2000; Dattner, 2011) indicates that first-born children are more confident, assertive and concerned about position and rank. Other attributes associated with first-born and only children include high-achievement orientation, high level of motivation, and leadership. The typical characteristics attached to birth order may influence personality and, therefore, behaviour in the workplace. Other demographic variables identified in literature as potentially impacting on professional success are gender of siblings, ethnicity, education level, parent's education level and profession, marital status and number and age of children (Punnett et al., 2006).

\subsubsection{Career barriers}

Women's career progress appears to be influenced by what has been termed a glass ceiling, denoting a continued artificial barrier to the advancement by women to executive positions (Bagues \& Estev-Volart, 2010). The most prominent barriers identified in the literature include gender and leadership stereotyping. Research into the stereotyping of gender roles globally illustrates the common belief that women are inferior to men and that they lack the ability to deal with the challenges of senior management. Gender stereotypes extend to leadership stereotypes, with the tendency to associate the profile of a competent manager or leader with typical male characteristics (Fels, 2004; Fox \& Lawless, 2004; Bolton \& Muzio, 2005; De Vries, 2006; Singh, Vinnicombe \& James, 2006; Bilimoria \& Piderit, 2007; Ryan \& Haslam, 2007; Sealy \& Singh, 2009).

Further barriers to women's career progress reported in literature are an inhospitable organisational culture (O'Connor, 1996; Bilimoria $\&$ Piderit, 2007), a lack of female mentors and 
role models (Singh, et al., 2006; Sealy \& Singh, 2009), social exclusion from male networks (Simpson \& Altman 2000; Kephart \& Schumacher, 2005; Bilimoria \& Piderit, 2007; Cross \& Armstrong, 2008) and family responsibility (Legault \& Chasserio, 2003).

\subsubsection{Personality traits}

Hofstede (1997) argues that personality includes traits that are modified by the cultural environment and personal experiences of an individual. Personality characteristics identified in previous research as the best predictors of success are high self-efficacy (individuals' perceptions of their own effectiveness), an internal locus of control (individuals' confidence in their ability to control the outcomes of their actions) and a strong need to achieve (Duffy et al., 2006).

\subsubsection{Cultural factors}

The concept of collective mental characteristics or national cultural values dates back to the origins of populations, with opinion divided as to whether culture can be ascribed to nature (environment) or nurture (genetics). Hofstede's (1980; 1997) widely researched cross-cultural variables, regarded as influential in the achievement of success, are individualism/ collectivism (the degree to which a society values individual rather than group contributions); power distance (the degree to which a society regards inequality in power as appropriate); uncertainty avoidance (the degree to which a society values certainty more than ambiguity); and masculinity (the degree to which gender values are accepted by a society).

\subsubsection{External support}

External support in this article, briefly summarised in Table 2, refers to support initiatives external to the work environment that impact on women's ability to succeed.

\subsubsection{Internal support}

Internal support in this article is summarised in Table 3, and refers to organisational support for women for the purpose of enhancing their potential to succeed.

Table 2

External support factors in women's career advancement

\begin{tabular}{|l|l|l|}
\hline External support factor & \multicolumn{1}{|c|}{ Nature of contribution } \\
\hline Family support & $\begin{array}{l}\text { Assist women not to be primarily responsible for their } \\
\text { households and families. }\end{array}$ & Lockwood (2009). \\
\hline $\begin{array}{l}\text { Professional } \\
\text { associations for } \\
\text { networking }\end{array}$ & $\begin{array}{l}\text { Provide women with an alternative to internal } \\
\text { organisational networks from which they are excluded } \\
\text { owing to their homogenous nature. }\end{array}$ & $\begin{array}{l}\text { Palermo (2004); Vinnicombe, Singh and } \\
\text { Kumra (2004). }\end{array}$ \\
\hline Government initiatives & $\begin{array}{l}\text { Enforce women's appointment to leadership positions } \\
\text { through legislation. Examples include the Employment } \\
\text { Equity Act of 1998 in South Africa and quota legislation } \\
\text { introduced in a number of countries during the past } \\
\text { decade. }\end{array}$ & $\begin{array}{l}\text { Lewis and Rake (2008); Kilday, et al. } \\
\text { (2009); Coffman, Gadiesh and Miller } \\
\text { (2010). }\end{array}$ \\
\hline $\begin{array}{l}\text { Pressure from women's } \\
\text { groups and } \\
\text { organisations }\end{array}$ & $\begin{array}{l}\text { Impel government to consider further legislation and } \\
\text { initiatives to remove exclusionary practices impacting } \\
\text { on women's career advancement. }\end{array}$ & $\begin{array}{l}\text { Sweetman (2000); Kerr and Sweetman } \\
\text { (2003); Murgolo-Poore (2006). }\end{array}$ \\
\hline $\begin{array}{l}\text { Awards for successful } \\
\text { women and role models }\end{array}$ & $\begin{array}{l}\text { Serve as motivation and an indicator that career } \\
\text { success is achievable. }\end{array}$ & BWASA (2010). \\
\hline
\end{tabular}

Table 3

Internal support factors in women's career advancement

\begin{tabular}{|l|l|l|}
\hline \multicolumn{1}{|l|}{ Internal support factor } & \multicolumn{1}{|c|}{ Nature of contribution } & \multicolumn{1}{c|}{ Source } \\
\hline Educational programmes & Has an impact on employability and career success. & De Vos and De Hauw (2010). \\
\hline $\begin{array}{l}\text { Transformation of } \\
\text { organisational culture }\end{array}$ & $\begin{array}{l}\text { Has an impact on way in which gendered identity and } \\
\text { roles are viewed. }\end{array}$ & $\begin{array}{l}\text { Kerr and Sweetman (2003); Palermo } \\
\text { (2004). }\end{array}$ \\
\hline $\begin{array}{l}\text { Management and } \\
\text { leadership style }\end{array}$ & $\begin{array}{l}\text { A more transformational or participative style is more } \\
\text { likely to support diversity than an autocratic or } \\
\text { transactional style. }\end{array}$ & $\begin{array}{l}\text { Eagly and Johannesen-Schmidt (2001); } \\
\text { Eagly and Carli (2003); Bilimoria and } \\
\text { Piderit (2007); DuBrin (2010). }\end{array}$ \\
\hline Coaching and mentoring & $\begin{array}{l}\text { Promote competency development; build confidence; } \\
\text { serve as gateway to senior staff; contribute to eradicating } \\
\text { structural and social barriers. }\end{array}$ & $\begin{array}{l}\text { Bilimoria and Piderit (2007); Ibarra, } \\
\text { Carter and Silva (2010); Peltier (2010). }\end{array}$ \\
\hline
\end{tabular}


There are a number of career barriers, as aforementioned, that influence the success of women and which culminate in a glass ceiling. Based on the literature review, it appears that barriers to career success can be transcended by means of internal and external support interventions. To guide the empirical research aimed at investigating factors influencing career success, a research framework was developed. Figure 1 outlines the research framework used in this study.

\section{3}

\section{Research framework of factors that influence career success}

The research framework for the empirical research is presented in Figure 1.

\section{Figure 1}

Research framework of factors influencing career success

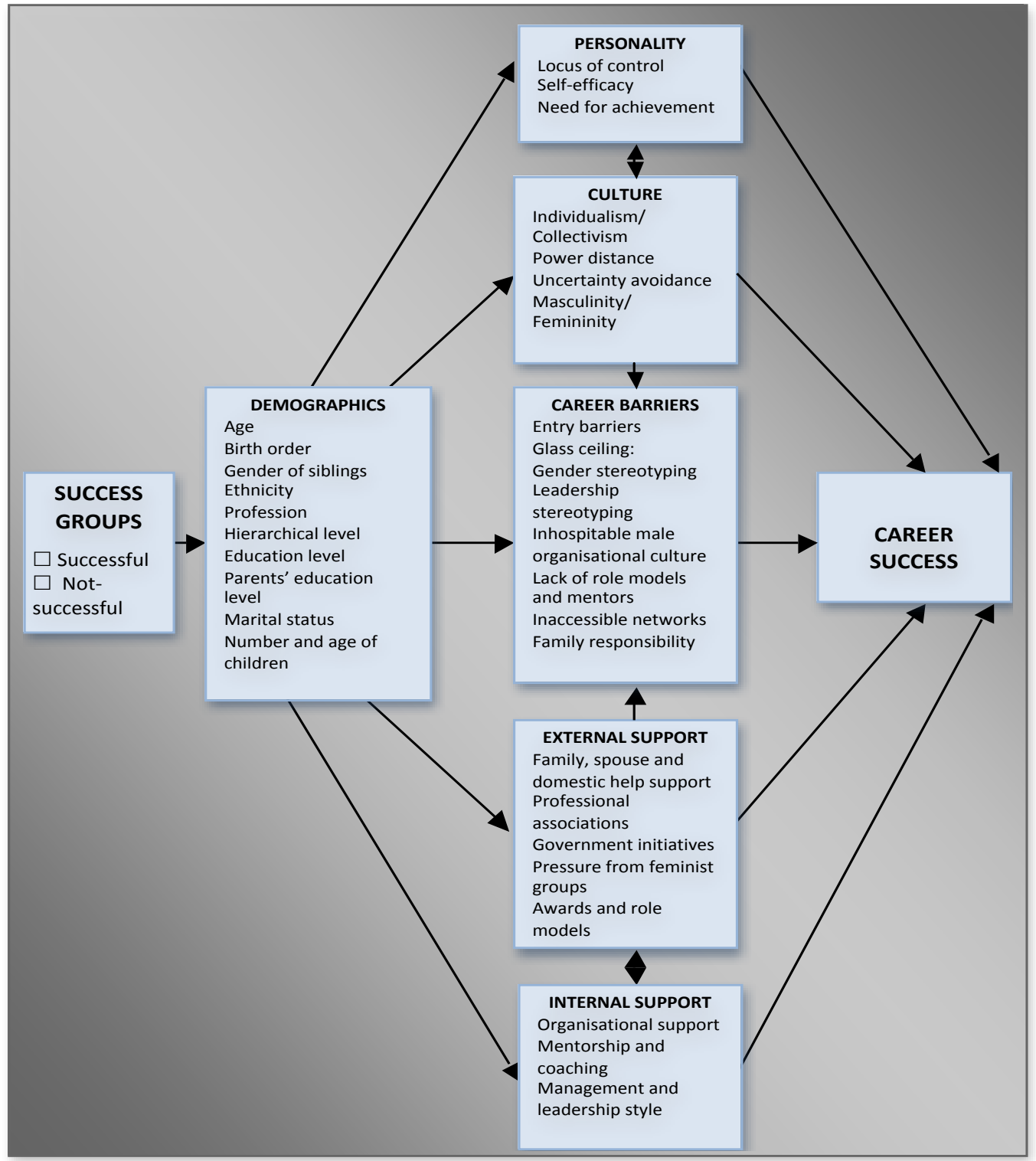

Source: Authors' own construct 
The research framework was used to investigate the factors (independent variables) hypothesised to influence career success. Success, the dependent variable, was used as an indicator to differentiate between women who have progressed to the top of the hierarchy in their organisation and those who have not yet done so.

\section{4}

\section{Research design and methodology}

The research paradigm employed was positivistic and, therefore, quantitative. Convenience sampling was employed and the empirical component of the research was demarcated to include a sample of 300 South African women in higher education, the accounting professions and the business sectors.

A measuring instrument was developed using existing validated scales where possible. Table 4 outlines the measuring instrument used to collect the empirical data.

Cronbach's alpha was calculated on each of the five factors indicated in Table 4 to test for internal consistency reliability of the measuring instrument. Cronbach's alpha was higher than 0.6 for all factors. It can thus be argued that the measures contained internal reliability (Berthoud, 2000; Hooper \& Zhou, 2007).

Table 4

The measuring instrument used in the study

\begin{tabular}{|c|c|c|c|}
\hline $\begin{array}{l}\text { Questionnaire } \\
\text { section }\end{array}$ & Factors measured & Scale used & $\begin{array}{l}\text { Number of } \\
\text { variables/ } \\
\text { questions }\end{array}$ \\
\hline \multicolumn{2}{|c|}{ Section A: Demographic data } & $\begin{array}{l}\text { Type: Categorical } \\
\text { Authors' own; Duffy et al. (2006) }\end{array}$ & 23 \\
\hline \multicolumn{2}{|c|}{$\begin{array}{l}\text { Section B: Perceptions of personality traits and cultural } \\
\text { environment }\end{array}$} & Type: Five-point Likert & \\
\hline \multicolumn{4}{|c|}{ Personality } \\
\hline & - Self-efficacy & Sherer et al. (1982); Chen et al. (2001) & 17 \\
\hline & - Locus of control & Spector (1988) & 16 \\
\hline & - Need for achievement & Jackson (1989) & 16 \\
\hline \multicolumn{4}{|c|}{ Culture } \\
\hline & - Power distance & Dorfman and Howell (1998) & 6 \\
\hline & - Uncertainty avoidance & Dorfman and Howell (1998) & 5 \\
\hline & - Individualism/collectivism & Dorfman and Howell (1998) & 5 \\
\hline & - Masculinity/femininity & $\begin{array}{l}\text { Dorfman and Howell (1998); Wu (2006); } \\
\text { Yoo et al. (2011) }\end{array}$ & 6 \\
\hline \multicolumn{2}{|c|}{$\begin{array}{l}\text { Section C: Perceptions of internal organisational and } \\
\text { external environment }\end{array}$} & Type: Five-point Likert & \\
\hline \multicolumn{4}{|c|}{ Barriers } \\
\hline & - Gender stereotyping & Authors' own, based on existing literature & 7 \\
\hline & - Leadership stereotyping & Authors' own, based on existing literature & 5 \\
\hline & - Lack of role models and mentors & Authors' own, based on existing literature & 2 \\
\hline & - Family responsibility & Authors' own, based on existing literature & 3 \\
\hline & - Inaccessible networks & Authors' own, based on existing literature & 1 \\
\hline & - Inhospitable organisational culture & Authors' own, based on existing literature & 1 \\
\hline \multicolumn{4}{|c|}{ Internal support } \\
\hline & - Organisational support & Authors' own, based on existing literature & 15 \\
\hline & - Mentoring and coaching & Tepper et al. (1996) & 5 \\
\hline & - Leadership and management style & Authors' own, based on existing literature & 2 \\
\hline \multicolumn{4}{|c|}{ External support } \\
\hline & - Family support & Authors' own, based on existing literature & 2 \\
\hline & - Professional associations & Authors' own, based on existing literature & 2 \\
\hline & - Government initiatives & Authors' own, based on existing literature & 4 \\
\hline
\end{tabular}




\begin{tabular}{|c|c|c|c|}
\hline $\begin{array}{l}\text { Questionnaire } \\
\text { section }\end{array}$ & Factors measured & Scale used & $\begin{array}{l}\text { Number of } \\
\text { variables/ } \\
\text { questions }\end{array}$ \\
\hline & $\begin{array}{l}\text { Pressure from feminist groups (degree } \\
\text { to which on-going interventions are } \\
\text { required) }\end{array}$ & Authors' own, based on existing literature & 2 \\
\hline & - Awards and role models & Authors' own, based on existing literature & 2 \\
\hline & - Spouse support & Authors' own, based on existing literature & 1 \\
\hline & - Domestic help support & Authors' own, based on existing literature & 1 \\
\hline
\end{tabular}

Data gathering was done through an online survey. Ten participating universities, Higher Education Resource Services South Africa (HERS-SA), the Business Women's Association of South Africa (BWASA) and the South African Institute of Chartered Accountants (SAICA) helped disseminate the survey through respectively their Human Resources departments (universities), website (HERS-SA) and newsletter (BWASA and SAICA), containing a link to the survey. Human Resources departments were requested to disseminate the survey to an inclusive group of academic and professional support staff at the higher end of the hierarchy in their respective institutions. With the target sample set for 300 , the survey was closed on 31 July 2011 when a total of 301 questionnaires were received.

Subsequent to obtaining descriptive statistics for the whole group $(n=301)$, the respondents were categorised into success groups using data from the descriptive statistics on three items from the demographic scale. The three items used to identify success groups were the age of the respondent, the number of years that the respondent was employed and the hierarchical level of the respondent. It was argued that:

If the respondent was at the top hierarchical level, then successful

If the respondent was at the middle hierarchical level, then:

If the respondent had been employed for fewer than five years OR the age of the respondent was less than 40 , then successful

If respondent had been employed for more than five years OR the age of the respondent was more than 40 , then not-successful

If the respondent was at the lower hierarchical level, then:

If the respondent had been employed for more than five years OR the age of the respondent was more than 40 , then not-successful
Women were thus regarded, for the purposes of the analysis as successful or not- successful according to the criteria outlined above.

\section{5}

\section{Findings}

For the findings, the profile of the respondents will first be outlined. Thereafter the results of more advanced statistics will be provided and discussed.

\subsection{Profile of respondents}

The results indicated that the respondents were predominantly in possession of post-graduate qualifications ( 85 per cent). A substantial percentage ( 52 per cent) had been employed for a relatively short period (1-9 years), yet the majority were between 35 and 49 years of age. A total of 41 per cent were eldest children, with a slightly higher percentage indicated in the successful category, supporting earlier research (Eckstein, 2000; Dattner, 2011) relating to the achievement-orientation of first-born children. Of the respondents who had siblings, the majority had only one (39 per cent) or two (20 per cent). The findings indicated that the number of siblings only discriminated between success groups when there were more than five siblings. Most of the respondents were married or in a permanent relationship. Of the respondents, 35 per cent had no children. Of those who had children, the majority (20 per cent) had children in the age group $18+$. The most notable variation between success groups in terms of the number of children was whether or not they had children. It appears that even having one child has the potential to effect women's careers, as indicated by a 26 per cent variation in success groups' achievement of success.

The respondents were generally ambitious, with 71 per cent aspiring to a higher 
hierarchical level in their organisation. Although the percentage was higher ( 82 per cent) for respondents in the not-successful category, more than 60 per cent of the respondents who were already categorised as successful aspired to higher levels.

\subsection{Results of advanced statistics}

Manova was employed to investigate differences between groups of women based on their demographics and selected variables. Manova was conducted with 17 demographic variables as independent variables with the factors influencing career success such as personality, culture, career barriers, internal support and external support as dependent variables. The findings are presented in Table 5 with significant $\mathrm{p}$-values indicated by an asterisk $(*)$.

Table 5

Manova tests of significance - profile of all dependent variables

\begin{tabular}{|c|c|c|c|}
\hline 7 & $\mathbf{F}$ & DF & $\mathbf{p}$ \\
\hline Hierarchical level & 1.2919 & $44 ; 452$ & .106 \\
\hline Hierarchal level aspiring to & 1.8749 & $22 ; 226$ & $.012^{*}$ \\
\hline Salary range & 1.2124 & $110 ; 1112.0$ & .075 \\
\hline Years of service & 0.9177 & $66 ; 675.8$ & .661 \\
\hline Age & 1.1954 & $44 ; 452$ & .190 \\
\hline Birth order & 1.7876 & $66 ; 675.8$ & $.000^{*}$ \\
\hline Profession & 1.7922 & $66 ; 675.8$ & $.000^{*}$ \\
\hline Marital status & 3.0669 & $44 ; 452$ & $.000^{*}$ \\
\hline Number of children & 1.2546 & $66 ; 675.8$ & .092 \\
\hline Age groups of children: $<3$ & 1.2737 & $22 ; 226$ & .191 \\
\hline Age groups of children: 3-6 & 1.0025 & $22 ; 226$ & .462 \\
\hline Age groups of children: 7-12 & 1.8422 & $22 ; 226$ & $.015^{*}$ \\
\hline Age groups of children: $13-17$ & 1.0162 & $22 ; 226$ & .445 \\
\hline Age groups of children: $18+$ & 2.5356 & $22 ; 226$ & $.000^{*}$ \\
\hline Father's education level & 1.1379 & $88 ; 896.1$ & .191 \\
\hline Mother's education level & 1.0102 & $88 ; 896.1$ & .457 \\
\hline
\end{tabular}

Manova results in Table 5 show the relationships between the hierarchical level of the respondents and their perceived extent of career success. Significant relationships were found between the hierarchical level to which respondents aspire $(\mathrm{p}=.012)$, their birth order $(\mathrm{p}=.000)$, their profession $(\mathrm{p}=.000)$, marital status $(\mathrm{p}=.000)$, children aged 7-12 $(\mathrm{p}=.015)$ and children older than $18(\mathrm{p}=.000)$. These results indicated that there were statistically significant differences in how respondents aspiring to different hierarchical levels perceived the factors that influenced their career success. Statistically significant relationships also existed in the extent to which the respondents perceived they had achieved career success for respondents from different birth orders, respondents from different professions, respondents with different marital status and respondents with children aged 7-12 and older than 18, and the factors that influenced their career success.

Manova was utilised to determine which dependent variables had a significant relationship with each of the selected independent variables. Step-wise discriminant analysis was subsequently employed to identify the factors which best differentiated between the success groups. Significant success factors were identified through a forward-stepping process using Wilks' Lambda as multivariate test of significance. Summary results of the forward stepping process are presented in Table 6 .

Factors identified as best discriminating between the groups as indicated in Table 6, were power distance, uncertainty avoidance, masculinity/femininity, gender stereotyping and lack of role models and mentors. F-tests were 
performed to test for statistical significance and a statistically significant F-value (p-value $<0.05$ ) indicated a difference between the groups of women with reference to the independent variables. Statistically significant p-values were observed for power distance (.012), uncertainty avoidance (.014), masculinity/ femininity (.025), gender stereotyping (.019) and lack of role models and mentors $(.020)$.

Table 6

Discriminant analysis - summary results of forward-stepping process

\begin{tabular}{|l|c|c|c|}
\hline \multicolumn{1}{|c|}{ Factor } & Wilks' Lambda & F-remove (1,288) & p-value \\
\hline Locus of control & 0.925 & 1.558 & .213 \\
\hline Power distance & 0.941 & 6.431 & $\mathbf{. 0 1 2}^{\boldsymbol{*}}$ \\
\hline Uncertainty avoidance & 0.940 & 6.094 & $\mathbf{. 0 1 4}^{*}$ \\
\hline Masculinity/femininity & 0.936 & 5.091 & $\mathbf{. 0 2 5}^{*}$ \\
\hline Gender stereotyping & 0.938 & 5.555 & $\mathbf{. 0 1 9}^{*}$ \\
\hline Lack of role models and mentors & 0.937 & 5.442 & $\mathbf{. 0 2 0}^{*}$ \\
\hline Family responsibility & 0.925 & 1.382 & .241 \\
\hline
\end{tabular}

*Significant at $p<0.05$

T-tests were conducted to make inferences about how the two success groups compared with regard to the factors influencing their career success. Table 7 provides the p-values obtained from the t-tests, with significant $\mathrm{p}$ values indicated by an asterisk $(*)$.

Table 7

T-test results of women success groups and factors influencing career success

\begin{tabular}{|l|c|}
\hline \multicolumn{1}{|c|}{ Factor } & P-value \\
\hline Self-efficacy & .372 \\
\hline Locus of control & .088 \\
\hline Need for achievement & .363 \\
\hline Power distance & .467 \\
\hline Individualism/collectivism & .735 \\
\hline Uncertainty avoidance & $.017^{*}$ \\
\hline Masculinity/femininity & $.039^{*}$ \\
\hline Stereotyping & .103 \\
\hline Lack of role models and mentors & .211 \\
\hline Family responsibility & .912 \\
\hline Inaccessible networks & .797 \\
\hline Inhospitable organisational culture & .420 \\
\hline Organisational support & .168 \\
\hline Mentoring and coaching & .977 \\
\hline Leadership and management style & .275 \\
\hline Family support & .384 \\
\hline Professional associations & .803 \\
\hline Government initiatives & .656 \\
\hline Pressure from feminist groups & .118 \\
\hline Awards and role models & .473 \\
\hline Spouse support & .409 \\
\hline Domestic support & .719 \\
\hline
\end{tabular}

*Significant at $p<0.05$ 
As illustrated by the p-values presented in Table 7, no significant differences were found, with the exception of two of the cultural factors, uncertainty avoidance and masculinity/ femininity where statistically significant differrences were found between the success groups of women. The not-successful group appeared to value certainty, rather than a high degree of risk-taking, to a greater extent than the successful group. In terms of masculinity/ femininity, the successful group had a greater orientation towards femininity than the notsuccessful group, indicating that they believed more strongly in equal employment opportunities. Figure 2 provides a framework that incorporates the empirical results and is adjusted from the proposed framework in Figure 1.

Figure 2

Framework of results of the factors influencing career success

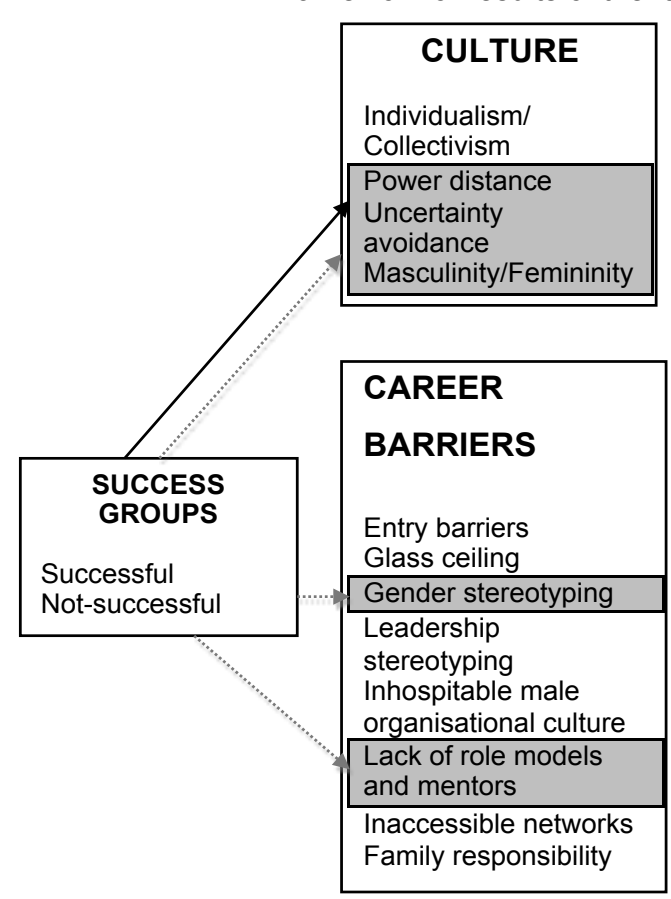

Source: Authors' own construct

6

\section{Conclusion}

This article explores factors perceived to influence women's career success. It provides a research framework of these factors, including demographics, career barriers, personality traits, culture, external support and internal support.

It can be concluded from the Manova results (Table 5) that statistically significant relationships were found in how respondents at different hierarchical levels perceived the

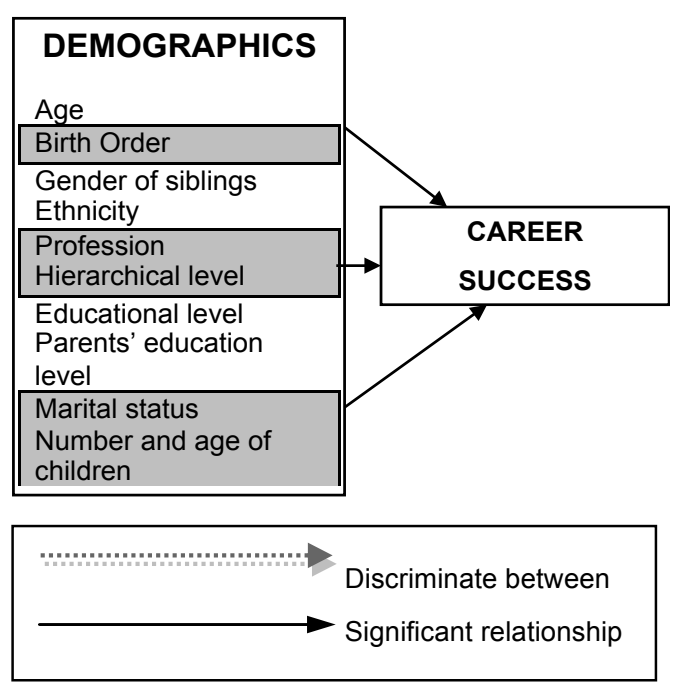

factors that influenced their career success. Statistically significant relationships were found for respondents from different birth orders, respondents from different professions, respondents with different marital status and respondents with children aged 7-12 and older than 18, and how they perceived the factors that influenced their career success. Statistically significant differences also existed for the extent to which the respondents perceived they had achieved career success. Although a higher percentage of respondents in the not-successful group aspired to a higher career level, more 
than half of the successful group of respondents also aspired to higher career levels. It can therefore be concluded that a substantial percentage of women are ambitious and that career progress is important to them.

The finding relating to birth order supports existing literature that first born children are generally achievement oriented and motivated, confident, assertive, and likely to exhibit leadership characteristics. A higher percentage of successful women were oldest children and a higher percentage of not-successful women were the youngest.

A notable variation between success groups were found for respondents from different professions. A meaningful variation between success groups in the business and professional sectors could indicate a higher degree of career challenges for women in these sectors when compared to the education sector, both academic and non-academic.

The largest relationship in terms of marital status was for women who were widowed, and to a lesser extent for women who were single, where there were more successful respondents in this category. In the divorced and married/ permanent relationship category there were a higher percentage of not-successful respondents.

Findings related to child care responsibilities associated with school-going children did not support literature indicating that this is a barrier to women's career success, where there were a higher percentage of respondents in the success group with children aged 7-12, and a higher percentage of respondents in the not-successful group who had children older than 18 .

Results from step-wise discriminant analysis (Table 6) further showed that the factors identified as best discriminating between successful women and not-successful women were power distance (the successful group to a greater extent advocated equality), uncertainty avoidance (the successful group were more willing to take risks), masculinity/femininity (the successful group had a greater orientation towards femininity and, therefore, a stronger belief in equal employment opportunities, also at the higher end of the hierarchy), gender stereotyping (the successful group appeared to experience gender stereotyping to a lesser extent) and lack of role models and mentors (the successful group experienced this to a higher extend). This is an area where organisations may need to intervene, as it may be assumed that women at the higher end of the hierarchy no longer require mentoring.

T-tests conducted (Table 7) showed only two statistically significant differences between the two success groups of women, uncertainty avoidance and masculinity/femininity.

The findings of this study supported earlier research that successful professional women are likely to demonstrate identified relationships and discriminating factors, but contradicted some of the earlier research with regards the nature of the relationships and discriminating factors. Culture is shown as the one factor that is important to career success of women. The revised framework indicated that only two of the factors, namely culture and career barriers, have significant relationships on career success of women. This is an important finding for focussing future research on the topic as it appears from the findings that societal changes with regard the sharing of family responsibilities, legislation, and organisational initiatives promoting equal opportunities, may have removed related barriers to women's career progression. The finding that personality factors identified in literature as contributing to the achievement of career success for women did not significantly discriminate between the success groups, may further be an indication that it can be excluded from research directed at the career advancement of women.

This article contributes to the existing literature by indicating which factors discriminate between successful and not-successful women. The development of a research framework for investigating the factors influencing the career success of professional and business women has set the scene for future enquiry on this topic.

\section{Acknowledgements}

The authors would like to thank the following: 
Mr Danie Venter of the Nelson Mandela Metropolitan University's Unit for Statistical Calculations, who conducted the statistical analysis for the empirical study.

Our sincere appreciation is extended to the reviewers for their time and effort in providing very valuable comments to improve the manuscript.

The Research Development Office of the Nelson Mandela Metropolitan University for the financial contribution that helped make this study possible.

\section{References}

BAGUES, M.F. \& ESTEVE-VOLART, B. 2010. Can gender parity break the glass ceiling? Evidence from a repeated randomized experiment. Review of Economic Studies, 77(4):1301-1328.

BERTHOUD, R. 2000. A measure of changing health. In Berthoud, R. \& Gershuny, J. (eds.) Seven years in the lives of British families: evidence on the dynamics of social change from the British household panel survey. Bristol: Policy Press.

BILIMORIA, D. \& PIDERIT, S.K. (eds.) 2007. Handbook on women in business and management. Cheltenham: Edward Elgar.

BOLTON, S. \& MUZIO, D. 2005. The paradoxical process of feminization in the professions: the case of established, aspiring and semi-professions. Work, Employment and Society, 22(2):281-299.

BWASA (Business Women's Association of South Africa). 2010. South African Business women of the year. Available at: http://www.bwasa.co.za/BusinesswomanoftheYear/BackgroundObjectives/tabid [accessed 2010-10-14].

BWA (Business Women's Association). 2012. South African women in leadership census 2012. Johannesburg: Business Women's Association of South Africa.

CHEN, G., GULLY, S. M., \& EDEN, D. 2001. Validation of a new general self-efficacy scale. Organizational Research Methods, 4(1):62-68.

COFFMAN, J., GADIESH, O. \& MILLER, W. 2010. The great disappearing act: Gender parity up the corporate ladder. Boston: Bain \& Company Inc.

CROSS, C. \& ARMSTRONG, C. 2008. Understanding the role of networks in collective learning processes: The experiences of women. Advances in developing human resources, 10(4):600-613. Available at: http://adh.sagepub.com [accessed 2009-3-13].

DAFT, R.L. 2010. New era of management $\left(9^{\text {th }}\right.$ ed.) Canada: South Western.

DATTNER, B. 2011. Birth order and personality in the workplace. New York: Dattner Consulting, LLC [PowerPoint Presentation]. Available at: http://www.dattnerconsulting.com/presentations/birthorder.pdf [accessed 2011-9-5].

DE VOS, A. \& DE HAUW, S. 2010. Linking competency development to career success: Exploring the mediating role of employability. Vlerick Leuven Gent Management School, Working Paper Series 2010/03. DE VRIES, J. 2006. Can't we just fix the women? Designing a women's leadership development program that challenges the organisation. Paper presented at CURTIN University of Technology. Changes, challenges, choices; Conference proceedings from the Inaugural International Women \& Leadership Conference, Fremantle, 16 and 17 November.

DORFMAN, P.W. \& HOWELL, J.P. 1988. Dimensions of national culture and effective leadership patterns: Hofstede revisited. Advances in International Comparative Management, 3:127-150.

DUBRIN, A.J. 2010. Principles of leadership. Kentucky: South Western Cengage Learning.

DUFFY, J.A., FOX, S., PUNNETT, B.J., GREGORY, A., LITUCHY, T.R., MONSERRAT, S.I., OLIVASLUJÁN, M.R., SANTOS, N. M. B. F. \& MILLER, J. 2006. Successful women of the Americas: The same or different? Emerald Management Research News, 29(9):552-571.

EAGLY, A.H. \& CARLI, L.L. 2003. The female leadership advantage. The Leadership Quarterly, 14: 807-834.

EAGLY, A.H. \& JOHANNESEN-SCHMIDT, M.C. 2001. The leadership styles of women and men. Journal of Social Issues, 57(4):781-797.

ECKSTEIN, D. 2000. Empirical studies indicating significant birth-order-related personality differences. The Journal of Individual Psychology, 56(4):481-494. 
FALK, E. \& GRIZARD, E. 2003. The glass ceiling persists: The $3^{\text {rd }}$ annual APPC report on women leaders in communication companies. Pennsylvania: The Annenberg Public Policy Center of the University of Pennsylvania.

FELS, A. 2004. Do women lack ambition? Harvard Business Review, April:1-9.

FOX, R.L. \& LAWLESS, J.L. 2004. Entering the arena: Gender and the decision to run for office. American Journal of Political Science, 48(2):264-280.

GRANT THORNTON, 2005. International business report. Available at: http://www.grantthorntonibos. com/files/IBOS-report-2005_final.pdf [accessed 2010-10-12].

HOFSTEDE, G. 1980. Culture's consequences: International differences in work-related values. Beverley Hills: Sage Publications.

HOFSTEDE, G. 1997. Cultures and organization: Software of the mind. New York: McGraw Hill. HOOPER, V. \& ZHOU, Y. 2007. Addictive, dependent, compulsive? A study of mobile phone usage. Paper presented at $20^{\text {th }}$ Bled Conference. Merging and emerging technologies, processes and institutions, Bled, Slovenia, 4-6 June.

IBARRA, H., CARTER, N.M. \& SILVA, C. 2010. Why men still get more promotions than women. Available at: http://hbr.org/2010/09/why-men-still-get-more-promotions-than-women/ar/1 [accessed 2010-10-17].

JACKSON, D.N. 1989. Personality research form manual. Port Huron, MI: Sigma Assessment Systems, Research Psychologists Press.

KEPHART, P. \& SCHUMACHER, L. 2005. Has the 'glass ceiling' cracked? An exploration of women entrepreneurship. Journal of Organizational Studies, 12(1):20-25.

KERR, J. \& SWEETMAN, C. (eds.) 2003. Women reinventing globalization. Sterling: Oxfam Publishing. KILDAY, L., MIHAILESCU, A., NOLAN, C. \& SCHREVE, F. 2009. Women on boards of directors: The case study of Norway. [Research Report]. Published in Husu, L., Hearn, J., Lämsä, A. \& Valhala, S. (eds.) 2010. Leadership through the gender lens: women and men in organisations. Helsinki: Hanken School of Economics.

LEGAULT, M.H. \& CHASSERIO, S. 2003. Family obligations or cultural constraints? Obstacles in the path of professional women. Journal of International Women's Studies, 4(3):108-125.

LEWIS, R. \& RAKE, K. 2008. Breaking the mould for women leaders: could boardroom quotas hold the key? A Fawcett Society think piece for the Gender Equality Forum. Available at: http://www.eve-olution.net/ documents/pdf/boardroom_quotas.pdf [accessed 2010-11-17].

LOCKWOOD, N.R. (project leader). 2009. Perspectives on women in management in India. Mumbai: Society for Human Resource Management.

MURGOLO-POORE, M. 2006. Feminist social constructionist theory put to the test: Paper presented at CURTIN University of Technology. Changes, challenges, choices; Conference proceedings from the Inaugural International Women \& Leadership Conference, Fremantle, 16 and 17 November.

O' CONNOR, P. 1996. Organisational culture as a barrier to women's promotion. The Economic and Social Review, 3:187-216.

PALERMO, J. 2004. Breaking the cultural mould: The key to women's career success. Paper commissioned by Hudson Global Resources \& Human Capital Solutions. Available at: http://www.hudson.com [accessed 2010-8-17].

PATON, N. 2008. Downturn could make glass ceiling even thicker. Available at: http://www.managementissues.com/.../downturn-could-make-the-glass-ceiling-even-thicker.asp [accessed 2009-3-18].

PELTIER, N. 2010. The psychology of executive coaching: Theory and application. $\left(2^{\text {nd }}\right.$ ed.) New York: Routledge.

PUNNETT, B.J., DUFFY, J.A., FOX, S., GREGORY, A., LITUCHY, T.R., MONSERRAT, S.I., OLIVASLUJÁN, M.R. \& SANTOS, N.M.B.F. 2006. Successful professional women of the Americas: From polar winds to tropical breezes. Cheltenham: Edward Elgar.

RYAN, M.K. \& HASLAM, S.A. 2007. The glass cliff: exploring the dynamics surrounding the appointment of women to precarious leadership positions. Academy of Management Review, 32(2):549-572.

SEALY, R.H.V. \& SINGH, V. 2009. The importance of role models and demographic context for senior women's work identity development. International Journal of Management Reviews:1-20. 
SHERER, M., MADDUX, J. E., MERCANDANTE, B., PRENTICE-DUNN, S., JACOBS, B., \& ROGERS, R.W. 1982. The self-efficacy scale: construction and validation. Psychological Reports, 51:663-671.

SIMPSON, R. \& ALTMAN, Y. 2000. The time bounded glass ceiling and young women managers: Career progress and career success - evidence from the UK. Journal of European Industrial Training, 24(1): 190-198.

SINGH, V., VINNICOMBE, S. \& JAMES, K. 2006. Constructing a professional identity: how young female managers use role models. Women in Management Review. Available at: http:/www.cranfield.ac.uk [accessed 2010-8-16].

SOUTH AFRICA. 1998. Employment Equity Act 55 of 1998. Pretoria: Government printer.

SPECTOR, P.E. 1988. Development of the work locus of control scale. Journal of Occupational Psychology, 61:335-340.

SWEETMAN, C. (ed.) 2000. Women and leadership. London: Oxfam Publishing.

TEPPER, K., SHAFFER, B.C. \& TEPPER, B.J. 1996. Latent structure of mentoring function scales. Educational and Psychological Measurement, 56(5):848-857.

VINNICOMBE, S., SINGH, V. \& KUMRA, S. 2004. Making good connections: Best practice for women's corporate networks. Cranfield: Cranfield University School of Management.

WU, M.Y. 2006. Hofstede's cultural dimensions 30 years later: A study of Taiwan and the United States. Intercultural Communication Studies, XV:33-42.

YÁÑEZ J.L. \& MORENO, M.S. 2008. Women leaders as agents of change in higher education organizations. Gender in Management: An International Journal, 23(2):86-102.

YOO, B., DONTHU, N. \& LENARTOWICZ, T. 2011. Measuring Hofstede's five dimensions of cultural values at the individual level: Development and validation of CVSCALE. Journal of International Consumer Marketing, 23(3-4):193-210. 